\title{
Acidic Wet Deposition in Bandung City Indonesia
}

\author{
Nia Yuniarti Hasan ${ }^{1}$, Driejana ${ }^{2}$, Aminudin Sulaeman $^{3}$ and Herto Dwi Ariesyady ${ }^{4}$ \\ ${ }^{1}$ Environmental Engineering Doctoral Program, Institut Teknologi Bandung, Jl. Ganesa 10, Bandung 40132. \\ ${ }^{2}$ Air and Waste Management Research Group, Faculty of Civil and Environmental Engineering, Institut Teknologi Bandung, Jl. \\ Ganesa 10, Bandung 40132. \\ ${ }^{3}$ Analytical Chemistry Research Group, Faculty of Mathematics and Natural Science, Institut Teknologi Bandung, Jl. Ganesa 10, \\ Bandung 40132. \\ ${ }^{4}$ Environmental Technology and Management Research Group, Faculty of Civil and Environmental Engineering, Institut Teknologi \\ Bandung, Jl. Ganesa 10, Bandung 40132.
}

\begin{abstract}
Acidic deposition (acid rain) has been known to cause negative impact to environment. Measurement of rain chemical composition was done in March to August 2016 to investigate temporal variation of atmospheric deposition in Bandung City. Rainwater samples are collected at four sampling sites. The chemical properties of the rain determined were $\mathrm{pH}$ and ionic concentrations of $\mathrm{SO}_{4}{ }^{2}-, \mathrm{NO}_{3^{-}}, \mathrm{Cl}^{-}$, $\mathrm{Ca}^{2+}, \mathrm{Mg}^{2+}, \mathrm{Na}^{+}, \mathrm{K}^{+}$and $\mathrm{NH}_{4}^{+}$. The rainwater was typically acidic with the range of mean $\mathrm{pH}$ between 5.29 - 5.56 and mean electric conductivity value range between $16.37-19.96 \mu \mathrm{S} / \mathrm{cm}$. Temporal variation showed higher $\mathrm{SO}_{4}{ }^{2+}, \mathrm{NO}_{3}{ }^{+}$and $\mathrm{NH}_{4}{ }^{+}$concentration in August when rainfalls were the lowest $(214.88 \mathrm{~mm})$. Similar temporal variation for the mean $\mathrm{pH}(5.98)$ and electric conductivity $(25.36 \mu \mathrm{S} / \mathrm{cm})$ in August. $\mathrm{Ca}^{2+}$ highest concentration was observed in June. Generally, the the major component of precipitation chemistry were $\mathrm{SO}_{4}{ }^{2-}$ and $\mathrm{NO}_{3}{ }^{-}, \mathrm{Ca}^{+}$and $\mathrm{NH}_{4}{ }^{+}$, for anion and cations, respectively. The largest proportions of the total anions in all sampling sites was $\mathrm{SO}_{4}{ }^{2-}$ ranged from 32\% (Lembang) to $37 \%$ (Buah Batu) followed by $\mathrm{NO}_{3}{ }^{-}$ $(13-15 \%)$ and and $\mathrm{Cl}^{-}(4-7 \%)$. For cations, $\mathrm{NH}_{4}{ }^{+}$dominated with proportion ranged between $21-27 \%$ and subsequently $\mathrm{Ca}^{2+}(13-19 \%)$ and followed by $\mathrm{Na}^{+}, \mathrm{Mg}^{+}, \mathrm{K}^{+}$and $\mathrm{H}^{+}$. The Neutralizing Factor (NF) results reveal that $\mathrm{Ca}^{2+}$ and $\mathrm{NH}_{4}^{+}$are the dominant neutralization substances in the rainwater. However it should be noted that reduced nitrogen $\left(\mathrm{NH}_{4}{ }^{+}\right)$act as mobile nitrogen that further will acidify the environment, particularly to soil ecosystem downstreams.
\end{abstract}

\section{Introduction}

There are two meanings of wet deposition terms determined by The World Meteorological Organization (WMO). Firstly, wet deposition is a process of scavenging of any gases and/or particles from the atmosphere by liquid (i.e., water droplets) and solid (i.e., ice crystals) phases. The process involves removal of any species by droplets/ice crystals within clouds (i.e., in-cloud scavenging), and by falling drops/snowflakes (i.e., below-cloud scavenging). Second, wet deposition is the mass of material deposited from the atmosphere to the underlying surface in precipitation (over unit of area during unit of time) [1].

Acid deposition in the general is precipitation with a $\mathrm{pH}$ level of less than 5.6 and thus is considered to be acidic, and when it falls on the Earth it is considered to be "acid deposition." Acid deposition from atmospheric precipitation can makes soils, lakes and ponds become acidic. Sulfur dioxide and nitrogen oxides, typical air pollutants are transformed into sulfuric and nitric acid compounds in the atmosphere, with resultant changes of their properties. These acid compounds are carried by the wind as fine particles (aerosols) on sunny days. They dissolve in rain drops on rainy days or within clouds, then fall to the Earth's surface, making the environment acidic. Research has detected this transport on a continental scale, with effects extending beyond national borders [2].

Acid rain is a mild combination of mainly sulfuric and nitric acid. Sulfurous acid and nitrous acid are less stable and are present only in very low amounts. Sulfuric acid and nitric acid are the main acids present in acid rain. The problem occurs when rainwater combines with gaseous oxides of sulfur, nitrogen, and phosphoric and hydrochloric acid mists. The latter two and sulfur are released into the atmosphere from automobile exhausts, industries and electric power plants [3].

Nitrogen deposition has had a detrimental impact on temperate ecosystems resulting in soil acidification and a reduction in plant biodiversity. Soils release base cations during acidification process, such as calcium and magnesium, neutralizing the increase in acidity, if base cations have been depleted, aluminium was released from the soils, often reaching toxic levels was superseded by iron release into soil water [4].

Preliminary study evaluation of air quality in Bandung City showed factor characteristic of airborne

Corresponding author: driejana@tl.itb.ac.id 
particulate matter samples were attributed to sea salt, soil dust, vehicular emissions and biomass burning and industrial emissions. Many scale factories are located in and around the city with several pocket of slum areas, lacking waste disposal system, rapid growth of industry, residential area, population and motor vehicle has caused air pollutant problem in Bandung City [5].

Wet deposition is the most effective scavenging process to removing particulate and gaseous air pollutant from atmosphere in Bandung City. We present the precipitation chemistry and wet deposition that occurred at four sampling sites in Bandung City from February to August 2016. Weekly bulk precipitation chemistry samples were analyzed for the anion of $\mathrm{SO}_{4}{ }^{2-}, \mathrm{NO}_{3}{ }^{-}, \mathrm{Cl}^{-}$ and for the cations of $\mathrm{Ca}^{2+}, \mathrm{Mg}^{2+}, \mathrm{Na}^{+}, \mathrm{K}^{+}$and $\mathrm{NH}_{4}^{+}$in additional to $\mathrm{pH}$ and conductivity measurement.

\section{Material and Method}

Rain water samples were collected on a weekly basis in four sampling stations from March 2016 to August 2016. These stations were distributed in Bandung City. The locations of the sampling sites were chosen in order to represent various geographical conditions and expected pollution levels and are presented in Figure 1.

Three of the sampling sites are placed in urban areas. The first installed in an altitude of $1271 \mathrm{~m}$ asl at Lembang farming area. The second was installed at an altitude of $803 \mathrm{~m}$ asl in Coblong area and the third was installed at an altitude of $742 \mathrm{~m}$ asl in Sumur Bandung . The fouth was installed at an altitude of $642 \mathrm{~m}$ asl at Buah Batu area.

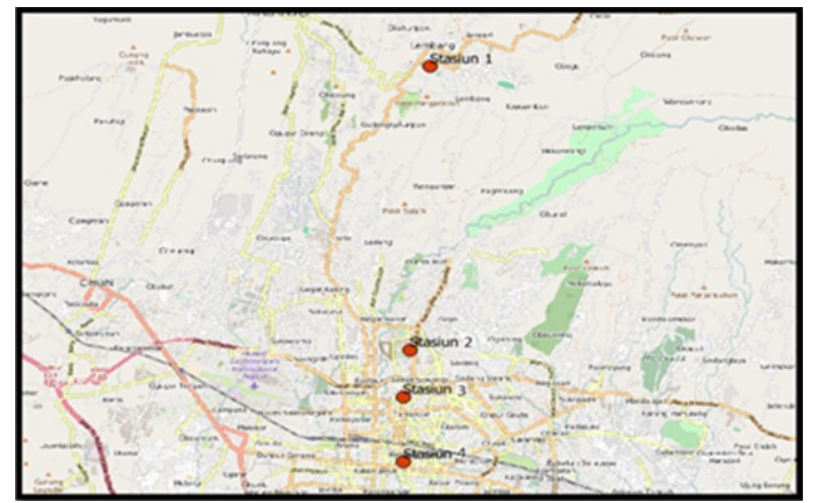

Fig. 1. Sampling site

\subsection{Sampling Equipment and Methods}

The rainwater samples was collected manually using a polyethylene bottle $(1000 \mathrm{~mL})$ with a polyethylene funnel (12 $\mathrm{mm}$ in diameter) and put on a stainless steel cylinder. The funnel equipped with a filter plug $(1 \mathrm{~mm}$ mesh) to protect large debris. The inside wall of canister painted with black color to diminish light levels around the collecting bottle and to inhibit biological growth [6].

Rainwater sampling was collected on a weekly basis from March to August 2016. The bulk collector bottle was replaced with a clean one and funnels were rinsed with deionized water. Samples bottle were placed in a cool box with blue ice and were transported from the sampling sites to the laboratory.

\subsection{Laboratory Analysis Method}

Upon arrival at the laboratory, samples were immediately weighed for volume determination, followed by $\mathrm{pH}$ measurement (Sartorius Professional Meter PP-20) and electric conductivity (Agilent Technologies $3200 \mathrm{C}$ ). The $\mathrm{pH}$ meter and conductivity meter were calibrated before measurement. Samples were sealed from the atmosphere and stored in the dark at $4^{\circ} \mathrm{C}$ in the refrigerator until analysis. Major ions $\left(\mathrm{SO}_{4}{ }^{2}\right.$, $\mathrm{NO}_{3}^{-}, \mathrm{Cl}^{-}, \mathrm{Ca}^{2+}, \mathrm{Mg}^{2+}, \mathrm{Na}^{+}, \mathrm{K}^{+}$and $\mathrm{NH}_{4}^{+}$) were analysis using ion chromatograph DIONEX ICS 500 DP.

\subsection{Quality Assurance}

\subsection{1 lonic Balance (IB)}

The accuracy of laboratory analysis was determined using ion balance analysis. Ionic Balance is the sum of major anions in a water sample that is theoreticaly should equal to sum of major cations. In reality, factors such as the presence of unknown ions that have not been analyzed, analytical error or measurement precision could cause differences in ion balance (IB) was calculate by Equation 1 [6]:

$I B=\left(\sum_{\text {anions }}-\sum_{\text {cations }}\right) /\left(\sum_{\text {anion }}+\sum_{\text {cations }}\right) \times 100 \% \%_{\mathrm{s}}$

It is suggested that the difference between ions were $\mathrm{IB} \pm 8 \%$ if sum ions $>100 \mu \mathrm{eq} / \mathrm{L}, \mathrm{IB} \pm 15 \%$ if sum ions $50-100 \mu \mathrm{eq} / \mathrm{L}$ and $\mathrm{IB} \pm 30 \%$ if sum of ions $<50$ $\mu \mathrm{eq} / \mathrm{L}[2]$.

\subsubsection{Precipitation Weight Mean (PWM) Concentration}

In order to determine the influence of air pollution to rainwater chemistry, precipitation weighted mean (PWM) concentration was calculated to eliminate the effect of rainwater amount for each ion analyzed. PWM is carried out by summing the product of ion concentration and the precipitation amount, obtained from rainwater sampler, for each data pair and dividing the result by the sum of precipitation amount for a certain period [6].

$$
C_{w, j}=\Sigma C_{j, k} \cdot P_{k} / \Sigma P_{k \mathrm{~s}}
$$

where :

$\mathrm{C}_{\mathrm{w}, \mathrm{j}}$ : precipitation weighted concentration for ion $\mathrm{j}$ $\left(\mathrm{meqL}^{-1}\right)$

$\mathrm{Cj}, \mathrm{k}$ : ion $\mathrm{j}$ concentration in precipitation of time $\mathrm{k}$ $\left(\mathrm{meqL}^{-1}\right)$

$\mathrm{Pk}=$ precipitation amount of time $\mathrm{k}\left(\mathrm{mm} \mathrm{time}^{-1}\right)$ 


\section{Result and Discussion}

\subsection{Precipitation Chemistry}

Generally $\mathrm{SO}_{4}{ }^{2-}$ and $\mathrm{NO}_{3}{ }^{-}$for anion and $\mathrm{Ca}^{2+}$ and $\mathrm{NH}_{4}{ }^{+}$ for cations, were found as major component in precipitation chemistry, at all sampling sites (Table 1). Table 1 present mean, minimum and maximum of $\mathrm{pH}$, conductivity and concentration of major ions in rainwater in Bandung City. Mean concentration of $\mathrm{SO}_{4}{ }^{2-}$ ranged from $39.90 \mu \mathrm{eq} / \mathrm{L}$ (at Lembang) to $78.76 \mu \mathrm{eq} / \mathrm{L}$ (at Sumur Bandung) and mean concentration of $\mathrm{NO}_{3}^{-}$ ranged from 19.47 (at Lembang) to $27.41 \mu \mathrm{eq} / \mathrm{L}$ (at Sumur Bandung). Mean concentration of $\mathrm{Ca}^{2+}$ ranged from $31.43 \mu \mathrm{eq} / \mathrm{L}$ (at Coblong) to $51.61 \mu \mathrm{eq} / \mathrm{L}$ (at Lembang) and $\mathrm{NH}_{4}^{+}$ranged from $29.07 \mu \mathrm{eq} / \mathrm{L}$ (at Lembang) to $49.70 \mu \mathrm{eq} / \mathrm{L}$ (at Sumur Bandung).

Gaseous pollutant such as $\mathrm{SO}_{2}$ and $\mathrm{NO}_{\mathrm{x}}$ are released into the atmosphere when fuels such as oil and coal are burnt. $\mathrm{SO}_{2}$ and $\mathrm{NO}_{\mathrm{x}}$ are the major causative agents (precursors) of acid deposition. The high concentrations of alkaline ions (mainly $\mathrm{Ca}^{2+}, \mathrm{NH}_{4}^{+}$) in the atmosphere have played an important role to neutralize the acidity of rainwater, but it is worth noting that the emission of $\mathrm{NO}_{\mathrm{x}}$ from the automobile exhaust is increasing and becoming the important precursor of acid rain [7].

We observed that the lowest mean rainwater $\mathrm{pH}$ value in Buah Batu was 5.28 which was less than $\mathrm{pH}$ value of 5.6 of unpolluted rainwater at equilibrium with atmospheric $\mathrm{CO}_{2}$ [8]. Carbonic acid is a weak acid, it brings down the $\mathrm{pH}$ of the rainwater to $6.0-5.2$. With $\mathrm{pH}$ levels ranging between $6.0-5.2$, rainwater is acidic, but still not dangerous. This is a reversible reaction. Sometimes, the $\mathrm{pH}$ level can even become as low as 2 . This phenomenon of acidic rainwater precipitation, is called acid rain.

The mean electric conductivity in rainwater samples ranged from $15.67 \mu \mathrm{S} / \mathrm{cm}$ at Buah Batu $-19.37 \mu \mathrm{S} / \mathrm{cm}$ at Sumur Bandung. The common range of electric conductivity for precipitation sample is from $<0.5$ to $100 \mathrm{mS} / \mathrm{cm} \mathrm{[2].} \mathrm{Precipitation} \mathrm{conductivity} \mathrm{is} \mathrm{mainly}$ contributed by water soluble ions, the value being related to the total sum of anions and cations in the rainwater. Low precipitation conductivity is an indicator of good atmospheric environmental quality [9].

In term of ionic balance, more than $65 \%$ of the data is characterized by positive ionic balance value, which means the sum of anions in the samples exceeds that of cations. The chemical determination of heavy metals, aluminum, mercury, and organic compounds will aid in the characterization of precipitation if the ion balance not meet criteria [2].

\subsection{Temporal Variation of Precipitation Chemistry}

Monthly variation of precipitation chemistry is shown in Figure 2. Higher $\mathrm{SO}_{4}{ }^{2+}$ and $\mathrm{NO}_{3}{ }^{+}$anions concentration were observed in August $(89.41 \mu \mathrm{eq} / \mathrm{L}$ and $35.69 \mu \mathrm{eq} / \mathrm{L})$ and cation $\mathrm{NH}_{4}{ }^{+}(77.76 \mu \mathrm{eq} / \mathrm{L})$ when the lowest rainfall was observed $(214.88 \mathrm{~mm})$. But cation $\mathrm{Ca}^{2+}$ higest concentration $(94.27 \mu \mathrm{eq} / \mathrm{L})$ was observed in June $(521.67 \mathrm{~mm})$.

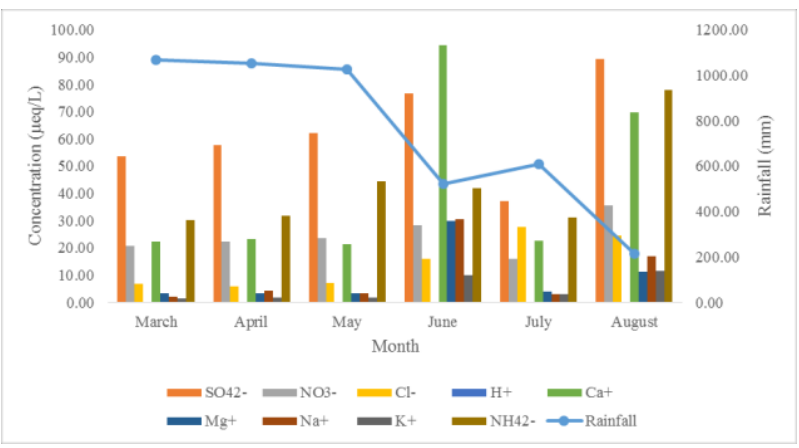

Fig. 2. Temporal variation of precipitation chemisty in Bandung City.

\subsection{Temporal Variation of $\mathrm{pH}$ and Electric Conductivity}

Temporal variation of $\mathrm{pH}$ and electric conductivity presented in Figure 3. Data show mean $\mathrm{pH}$ (5.98) and mean electric conductivity $(25.36 \mu \mathrm{S} / \mathrm{cm})$ were slightly higher in less rainy periods in August. This can be explained by the fact that, in drought periods, the atmosphere is considerably more polluted, so the wet scavenging process carries a higher load of compounds which increases both measured parameters.

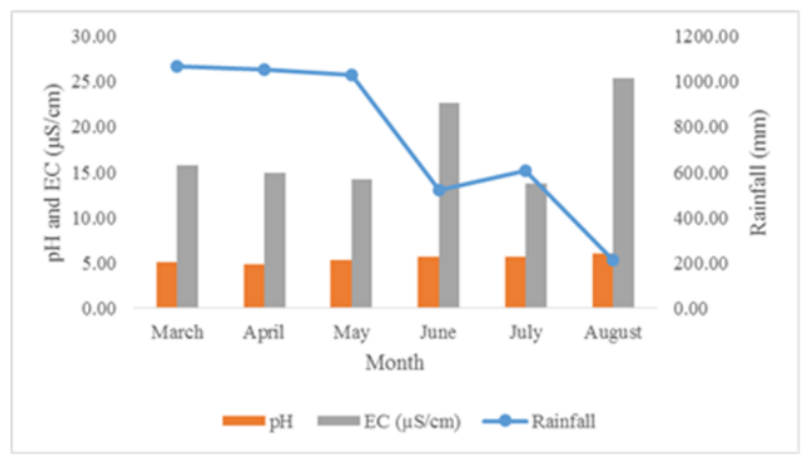

Fig. 3. Temporal variation of $\mathrm{pH}$ and electric conductivity in Bandung City emporal variation of precipitation chemisty in Bandung City 


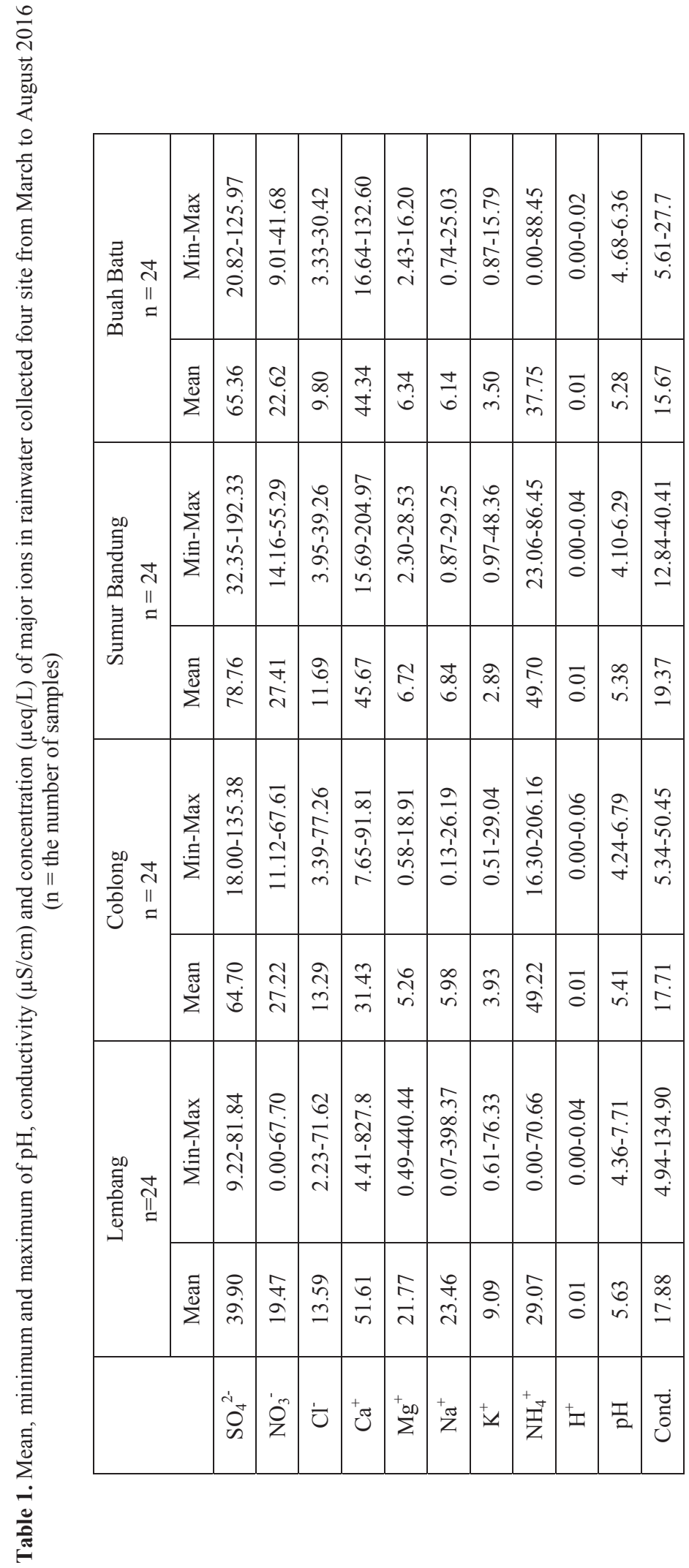




\subsection{Precipitation-weight Mean Concentrations (PWM)}

The proportion of Precipitation Weight Mean (PWM) concentrations in the rainwater sample shown the most anion components of rainwater sample in all sampling sites was $\mathrm{SO}_{4}{ }^{2-}$, which contributed for $32 \%$ (at Lembang) - $37 \%$ (at Buah Batu) to the total anions, followed by $\mathrm{NO}_{3}{ }^{-}(13-15 \%)$ and $\mathrm{Cl}^{-}(4-7 \%)$. Both $\mathrm{NH}_{4}{ }^{+}(21-$ $27 \%)$ and $\mathrm{Ca}^{+}(13-19 \%)$ were the major cations components, followed by $\mathrm{Na}^{+}, \mathrm{Mg}^{+}, \mathrm{K}^{+}$and $\mathrm{H}^{+}$.

Precipitation Weight Mean (PWM) concentrations in the rainwater sample for each sampling site location as shown in Figure 4, Figure 5, Figure 6, and Figure 7.

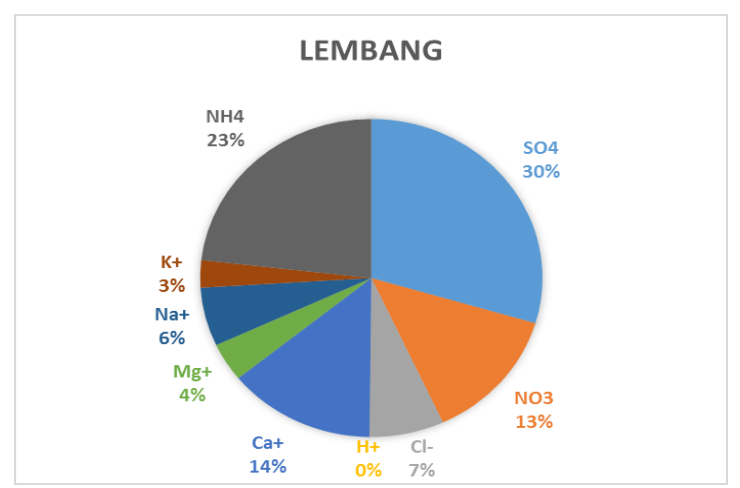

Fig. 4. Precipitation Weight Mean (PWM) concentration in Lembang

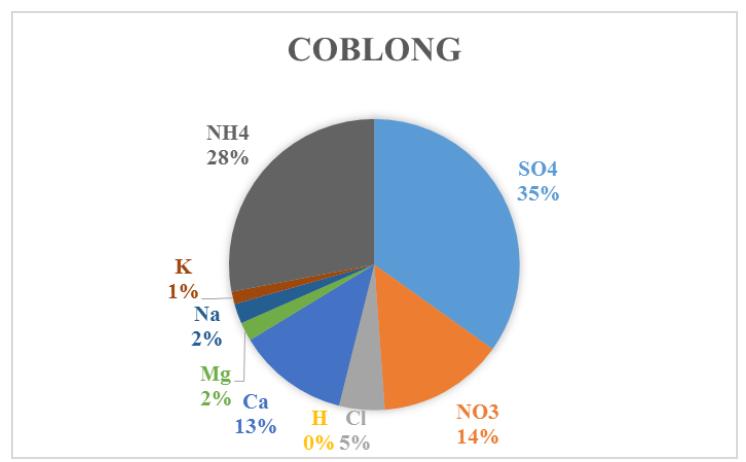

Fig. 5. Precipitation Weight Mean (PWM) concentration in Coblong

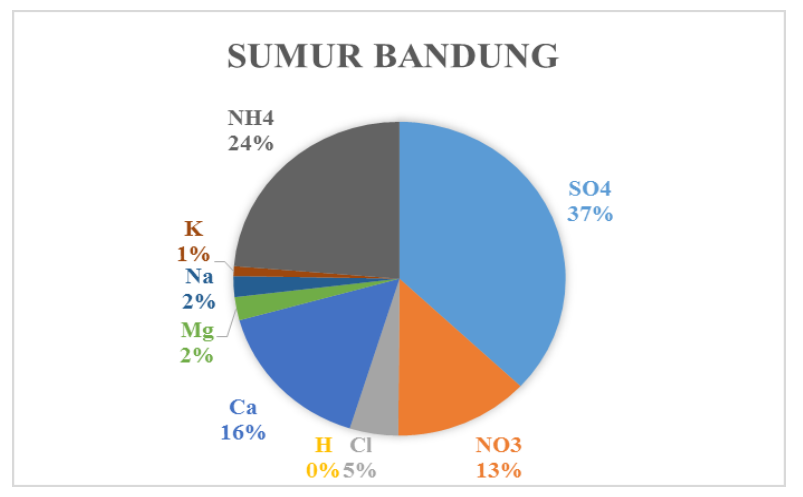

Fig. 6. Precipitation Weight Mean (PWM) concentration in Sumur Bandung

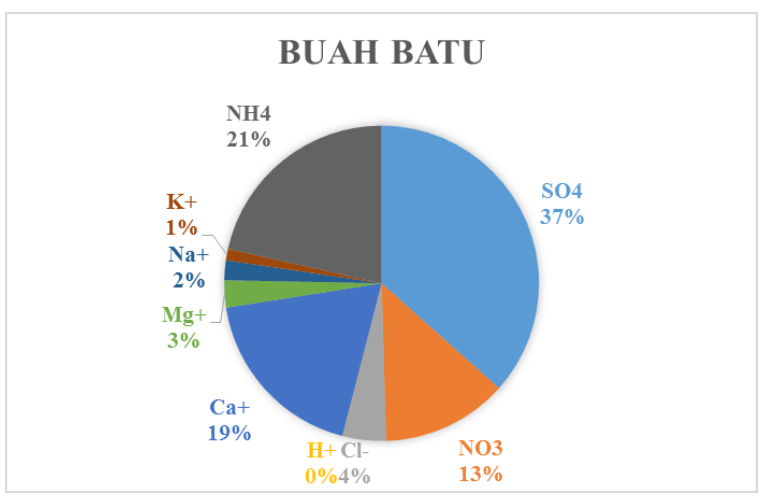

Fig. 7. Precipitation Weight Mean (PWM) concentration in Buah Batu

\subsection{Neutralizing Factor (NF)}

Neutralization factors (NF) can be used to evaluate the neutralization of precipitation by $\mathrm{Ca}^{2+}, \mathrm{Mg}^{2+}$ and $\mathrm{NH}_{4}^{+}$, which are calculated by the following Equation 3 $[10,11,12,13,6]$ :

$$
\mathrm{NF}_{\mathrm{Xi}}=\left[\mathrm{X}^{2+}{ }^{2+}\right] /\left[\mathrm{SO}_{4}^{2-}+\mathrm{NO}_{3}^{-}\right]
$$

where $\mathrm{Xi}$ is the chemical component of interest, with all the ions expressed in $\mu \mathrm{eq} / \mathrm{L}$.

The NF values for $\mathrm{Ca}^{2+}, \mathrm{Mg}^{2+}$ and $\mathrm{NH}_{4}^{+}$in rainwater of the study area are $0.87,0.37$ and 0.49 (at Lembang); 0.34, 0.06 and 0.54 (at Coblong); 0.43, 0.06 and 0.47 (at sumur Bandung) and 0.50, 0.07 and 0.43 (at Buah Batu). The results reveal that $\mathrm{Ca}^{2+}$ and $\mathrm{NH}_{4}^{+}$are the dominant neutralization substances in the rainwater. 


\subsection{Sources of Emission}

To identify the sources of emission which affects the quality of atmospheric precipitation was used to quantifies the sources emissions [14]. The result found ratio $\mathrm{SO}_{4}{ }^{2-} / \mathrm{NO}_{3}^{-}$were 2.05 (at Lembang), 2.38 (at Coblong), 2.87 (at Sumur Bandung) and 2.89 (at Buah Batu). The results showed that sulfuric emissions still dominated, however the ratio is not as high as the one found in cities affected by industry. Ratio $\mathrm{SO}_{4}{ }^{2-} / \mathrm{NO}_{3}{ }^{-}$at Dhanbad City, known as coal city in India was 16.94 due the fact that the site are located beside or in industrialized urban areas [14]. $\mathrm{SO}_{2}$ and $\mathrm{NO}_{\mathrm{x}}$ come from electric power generation that relies on burning fossil fuels, like coal [3].

Nitrate and sulfate are the major component of acid rain and their concentrations are increasing rapidly in the atmosphere growing to anthropogenic activities such as the burning of coal and petroleum fuels. Nitrogen in precipitation is present mainly as ammonium $\left(\mathrm{NH}_{4}{ }^{+}\right)$and nitrate $\left(\mathrm{NO}_{3}{ }^{-}\right) . \mathrm{NH}_{3}$ emissions sources from soils, oceans, and animal excreta. Sulfate in precipitation in different areas study were sea-salt sulfate, emissions of $\mathrm{SO}_{2}$ from industrialized areas and local sources as coal combustion and biogenic sulfur [15].

\subsection{Wet Deposition Rate}

Wet deposition rate for certain study periods were present in Table 2. The highest wet deposition rate of anion due to $\mathrm{SO}_{4}{ }^{2-}$ with mean ranged between 15.90 $\mathrm{kg} / \mathrm{ha}$ in Lembang to $45.45 \mathrm{~kg} / \mathrm{ha}$ in Sumur Bandung. For cations, wet deposition rate of $\mathrm{Ca}^{2+}$ ranged between $8.58 \mathrm{~kg} / \mathrm{ha}$ in Lembang to $11.60 \mathrm{~kg} / \mathrm{ha}$ in Buah Batu. $\mathrm{NH}_{4}{ }^{+}$has significant rate for cation in all sampling sites with range values between $4.60 \mathrm{~kg} / \mathrm{ha}$ in Lembang to $10.77 \mathrm{~kg} / \mathrm{ha}$ in Sumur Bandung.

Calcium is a major netralising agent that may play an important role in the precipitation chemistry in Bandung City. Calcium in rainwater may be contributed from soil dust, coal combustion and cement factories [16]. The neutralization capacity of soil dust from desert and semiarid areas northern China was largely related to the calcite $\left(\mathrm{CaCO}_{3}\right)$ content of the soil, so precipitation $\mathrm{pH}$ in this part of China has remained high despite the high sulfur emissions and large quantities of sulfuric acid in the precipitation. The chemical composition of the anthropogenic emitted calcium dust are not known, but is likely a combination of $\mathrm{CaCO}_{3}, \mathrm{CaO}$ and $\mathrm{CaSO}_{4}$ [17].

Table 2. Wet deposition rate $(\mathrm{kg} / \mathrm{ha})$

\begin{tabular}{|l|c|c|c|c|c|c|c|c|c|}
\hline \multirow{2}{*}{ Sampling Site } & \multirow{2}{*}{$\begin{array}{c}\text { Rainfall } \\
(\mathrm{mm})\end{array}$} & \multicolumn{3}{|c|}{ Anion $(\mathrm{kg} / \mathrm{ha})$} & \multicolumn{5}{c|}{ Cations $(\mathrm{kg} / \mathrm{ha})$} \\
\cline { 3 - 10 } & $\mathrm{Cl}$ & $\mathrm{NO}_{3}$ & $\mathrm{SO}_{4}$ & $\mathrm{Ca}$ & $\mathrm{Mg}$ & $\mathrm{Na}$ & $\mathrm{K}$ & $\mathrm{NH}_{4}$ \\
\hline Lembang & 829.88 & 4.00 & 10.02 & 15.90 & 8.58 & 2.20 & 4.48 & 2.95 & 4.35 \\
\hline Coblong & 1155.61 & 5.44 & 19.51 & 35.91 & 7.28 & 0.74 & 1.59 & 1.78 & 10.26 \\
\hline Sumur Bandung & 1201.52 & 4.98 & 20.42 & 45.45 & 11.00 & 0.98 & 1.89 & 3.36 & 10.77 \\
\hline Buah Batu & 1304.94 & 4.53 & 18.30 & 40.97 & 11.60 & 1.01 & 1.84 & 1.79 & 8.89 \\
\hline
\end{tabular}

\section{Conclusions}

The total amount of wet precipitation measured during the sampling period (March to August 2016) for Bandung City were ranged between $214.99 \mathrm{~mm}-$ $1067.32 \mathrm{~mm}$. The mean $\mathrm{pH}$ showed that samples had their majority acidic properties. This acidity was directly associated with $\mathrm{SO}_{4}{ }^{2-}$ and $\mathrm{NO}_{3}{ }^{-}$, where $\mathrm{SO}_{4}{ }^{2-}$ that were found to be the main contributor to this characteristic.

On the other hand, the neutralization process mainly originated from the presence of $\mathrm{Ca}^{2+}$ and $\mathrm{NH}_{4}^{+}$. Cation wet deposition rate of $\mathrm{Ca}$ has highest. Calcium is a major netralising agent that may play an important role in the precipitation chemistry in Bandung City. Ammonium $\left(\mathrm{NH}_{4}{ }^{+}\right)$came the second and showed significant rate for cation in all sampling site. There are not many agricultural areas in the city of Bandung. It is suggested that ammonia is originated from decomposition process of waste and wastewater mix in open channel in Bandung City are. However, this is still need further investigation.

This paper is part of the research "Prediksi Dampak Kesehatan Lingkungan Deposisi Basah Logam Berat di Wilayah Perkotaan Bandung" funded by Riset KK dan Inovasi ITB 2017.

\section{References}

1. A World Meteorogy Organization, Manual For The GAW Precipitation Chemistry Programme Guilines, Data Quality Objectives and Standard Operating Procedures, GAW Precipitation Chemistry Science Advisory Group, 2004 Amanded (2015)

2. M Acid Deposition Monitoring Network (EANET), Techical Manual for Wet Deposition Monitoring in East Asia, Network Center for EANET, (2015)

3. S. Bhargava, and S. Bhargava, Journal of Applied Chemistry 5, pp. 19 - 24, (2013)

4. W.D. Bowman, C.C. Cleveland, L. Halada, J. Hres, and J.S. Baro, Nature Geoscience 1, pp. 767 - 770, (2008)

5. D.D. Lestiani, M. Santoso, S. Kurniawati, and A. Markwitz, Indo. J. Chem., 13 (3), pp. 271 - 277, (2013)

6. D.W. Driejana, I.L. Raper, Gee, Air Pollution VIII, (WIT Press, Salt Lake City, UT, 2000)

7. H. Wang and G. Han, Atmospheric Research 99, pp. 190 - 196, (2011)

8. Seinfeld, H. John, Atmospheric Chemistry and Physics of Air Pollution, Jhon Wiley and Son, Inc., New York, (1986)

9. Y. Cheng, Y. Liu, M. Huo, Q. Sun, H. Wang, Z. Chen, Bai., Journal of Environmental Sciences, 23 (8), pp. 1350 - 1358, (2011)

10. K. Ali, G. Momin, S. Tiwari, P. Safai, D. Chate, P. Rao, Atmospheric Environment 38 (25), pp. 42154222, (2004) 
11. M. Possanzini, P. Buttini, V. Di Palo, Science of Total Environment 74, pp. 111 - 120, (1988)

12. T. Özsoy, P. Türker, S. Örnektekin, Water, Air, \& Soil Pollution 189, pp. 69-83, (2008)

13.P.R. Salve, A.A. Maurya, S.R. Wate, S. Devotta, Bulletin Environmental Contaminant Toxicology 80, pp. $242-246$, (2008)

14.P. Rai, International Journal of Current Engineering and Technology, 4 (2), pp. 673 - 679, (2014)

15.C.Q. Liu, and H.Y. Xiao, Atmospheric Environment 36, pp. 5121-5130, (2002)

16.Z. Xu, Y. Wu, W.J. Liu, C.H. Liang, J. Ji, T. Zhao, and $X$. Zhang, Atmospheric Research, 164 - 165, pp. $278-285$, (2015)

17.T. Larsen and G.R. Carmichael, Environmental Pollution 110, pp. 89 - 102, (2000)

18.R.M. Ceron, J.G. Ceron, C.G. Carballo, C.A. Aguilar, C. Montalvo, J.A. Benitez, Y.J. Villareal, and M.M. Gomez, Journal of Environmental Protection 4, pp. 50 - 56, (2013)

19.F.R.F. Cerqqueira, M.F. Pinto, I.N. Derossi, W.T. Esteves, M.D.R.S. Santos, R.C. Matos, Atmospheric Pollution Research 5, pp. 253-261, (2014) 